\title{
A STUDY OF ASSERTIVENESS IN A DEBATE SETTING
}

\author{
IgnasiaYuyun \\ Krida Wacana Christian University (UKRIDA), Jakarta, Indonesia \\ email: ignasia_y@ukrida.ac.id
}

\begin{abstract}
This article reports a study on the analysis of assertiveness of students' argument in a private senior high school debating's club. This study aims to identify the level of assertiveness of arguments in debating. The study employed mainly a qualitative method focusing on text analysis and involved a debating activity of senior high school students. World School Debating Championship style, Hallidayan's mood and modality analysis, and the theory of assertiveness in verbal communication became the basis of the analysis. seven phenomena were analyzed in this study including mood type, mood adjunct (conjunctive adjunct), mood metaphor, modality type, modality value, orientation and manifestation of modality, and modality metaphor. This study reveals that the level of assertiveness in argumentation is measured through the total number of declarative mood, conjunctive adjunct, high value of modality, explicit subjective modality, and explicit subjective modality metaphor. The study also shows that the level of assertiveness relatively depends on how the students deliver their arguments. Therefore, the students might need a variety of ways in order to make their argument sound more assertive.
\end{abstract}

Keywords: argument, assertiveness, debate, mood, mood metaphor, modality, modality metaphor, senior highschool, systemic functional

\begin{abstract}
Abstrak: Artikel ini melaporkan sebuah penelitian tentang analisis asertivitas dari argumen siswa yang tergabung dalam kelompok debat di sebuah Sekolah Menengah Atasswasta. Penelitian ini bertujuan untuk mengidentifikasi tingkat asertivitas dari argumen pada kegiatan debat. Penelitian ini menggunakan desain penelitian studi kasus kualitatif yang berfokus pada analisis teks dan melibatkan aktifitas debat siswa Sekolah Menengah Atas. Data diperoleh dari hasil observasi kegiatan debat siswa yang direkam dan dianalisis menggunakan teori debat, teori asertivitas dalam komunikasi verbal, dan analisismood dan modality dari Halliday. Analisis teks tersebut meliputi mood type, mood adjunct (conjunctive adjunct), mood metaphor, modality type, modality value, orientation and manifestation of modality, dan modality metaphor. Hasil temuan penelitian ini menunjukkan bahwa tingkat asertivitas dalam argumentasi diukur dengan jumlah total dari declarative mood, conjunctive adjunct, high value of modality, explicit subjective modality, dan explicit subjective modality metaphor. Penelitian ini juga menunjukkan bahwa tingkat asertivitas dipengaruhi oleh cara siswa menyampaikan argumen dalam berdebat. Oleh karena itu, siswa membutuhkan cara yang beragam untuk membuat argumen mereka lebih asertif.
\end{abstract}

Katakunci: argumen, asertivitas, debat, mood, modalitas,metafora modalitas

Argument and assertiveness are crucial in debating. An argument can be understood as a subset of assertiveness; all argument is assertive, but not all assertiveness involves argument such as a request (Rancer, 1998).An argument expresses and supports a contention or viewpoint on an issue and an issue is a matter of public debate on which there are different views (Mc Gregor, 2001, p. 2). In an argument, the author presents a point of view 
and attempts to persuade others of the validity of his or her opinion (Feez \& Joyce, 1998;Shulman, 2004, p. 148).Meanwhile, assertiveness includes characteristics of personal dominance, firmness, forcefulness, and the use of assertive behavior to achieve personal goals. In debating context, assertiveness is comprised of how one initiates and how one responds (Riddle, 2008) and it functions as fundamental qualities required to argumentation and persuasion in debating context(Braga \&Marques, 2004).

Regarding the issue being discussed, the assertiveness in this paper refers to the linguistic competence that speakers employ confidently to deliver their arguments in debating in order to keep debate flow and build mutual respect.Assertive words may include "I" statements ("I think" "I feel" "I want"), cooperative words ("let's" "how can we resolve this") and empathic statements of interest ("what do you think", "what do you say"). In line with this, as cited in Emilia (2009), when we write or deliver arguments, we use whatever language resources will work most effectively to sway the readers to our way of thinking (Feez \& Joyce, 1998, p. 141). Writers, Feez and Joyce further say, have a whole menu of different kinds of language to choose from when they write arguments, although of course they do not use all the items in every argument. For example, the use of words that show the author's attitude (modality), the use of words that express feelings (emotive words), the use of words to link cause and effect (thus, so, therefore, because,...).

Moreover, as discussed by Derewianka (1990. pp. 76-78), there are some common words, phrases, or expressions used in argumentation. These are, among others as follows: (1) generalised participants - some times human but often abstract (issues, ideas, opinions, etc) - unless the issue centres on a particular event or incident; (2) possibility of techical terms relating to the issue; (3) variety of verb (process types) - action, linking, saying (say, argue, point out, assert) and mental (think, perceive, understand); (4) mainly timeless present tense when presenting position and points in the argument, but might change according to the stage of the text; (5) frequent use of passives to help structure the text; (6) actions are often changed into "things" (nominalised) to make the argument sound more objective and to help structure the text; (7) connectives (conjunctions) associated with reasoning (therefore, so, because, because of, the first reason, etc); (8) arguments quite often employ emotive words (blatant disrespect, we strongly believe) and verbs such as "should". Such emotive language is more appropriate to spoken debate, and essays are generally more successful if the writer seeks to convince the reader through logic and evidence.

In addition to the language of arguments, Feez\& Joyce (1998, p.142) suggest the following characteristics: (1) introduces and sequences arguments by using linking devices such as first, second, furthermore, on the other hand, in conclusion, although, after looking at both sides of this debate; (2) focuses on the topic and organises arguments with topic sentences; (3) explains, describes, and uses evidence in arguments to make the arguments more 'factual' and so more powerful; (4) uses technical terms and abstract 'packaging' nouns; (5) shows cause and effect which are shown with words like "lead to"," contributes to", the consequence, cause; (6) judges and evaluates; (7) asseses degrees of what is probable or usual by using must, never, and inevitablyasses how probable or usual something is; (8) uses objective language; (9) attributes assessment to expert sources; and (10) appeals to the reader.

Apart from the linguistic features above, there are also some persuasive language techniques used by most people 
who write opinions and arguments to influence readers to accept or agree with arguments being expressed (Mc Gregor, 2000, pp. 5-6).

Based on the background above, the present study aimstoemploy systemic functional analysis especially mood and modality analysis to reveal the level of assertiveness of argument in senior high school debating.

\section{METHOD}

The subjects of this study were volunteers who are members of a debating club in a private senior high school in Bandung. They have been familiar with debating activity and debating competition for more or less one year.

Moreover, the procedures of data collections employedin this study were observationthrough video recording (Lutz \&Iannaccone 1969, cited in Marshall, et al. 2008) and discourse analysis (Travers 2001, p. 4). By making use of the observation, it was expected that the language competence in expressing arguments performed by senior high school debaters could be figured out obviously through recording. Moreover, the discourse analysis enabled the text of debate to be transcribed from the video into written text in a broad sense. Theexcerpts from the text werethen analysedon the basis of the following steps: dividing sentences carefully clause by clause, number the sentences and each clause, and code the elements to ease the analysis.

\section{FINDINGS AND DISCUSSION}

There are five elements that would be considered in measuring the level of assertiveness among six speakers in debating contest including the total of declarative mood, conjunctive adjunct, high value of modality, explicit subjective modality metaphor, and explicit subjective modality.
These elements are parts of mood and modality system.

\section{Declarative mood}

Declarative mood is a type of clauses (mood). Mood in English is pointed out by the position in the clause of the Subject Finite (Gerot\&Wignell, 1994, p. 38). Mood in functional grammar refers to whether a clause is indicative or imperative (Halliday\&Matthiessen, 2004, p. 134). In debating context, mood types play pivotal role to indicate the interpersonal meaning.

In the delivery of arguments, as throughout the debating, the most common sentence type by an overwhelming margin is declarative mood with positive polarity $(90 \%)$. These declarative statements are used to give information and convey certainty. As Halliday points out, a declarative sentence such as 'it is' conveys the highest possible degree of probability, more even than 'it must be' (1994, p. 357). In this case, the speakers wish to appear to be authoritative speaker whose opinions are not to be doubted.

Declarative was mostly employed by all speakers during debating, and appeared 430 times consisting of 394 full declaratives and 36 elliptical declaratives $(88 \%)$. These declarative statements were used to give initial information and factual information. The employment of this declarative could be seen from the following example quoted from Speaker \#1 of Affirmative Team:

Aff. 1:

1. (i) I'm as the first speaker of theAffirmative Team with the motion of "How to ban smoke advertisement on TV".

2. (ii) we know that cigarette is dangerous for our health, (iii) we know that in our country and in some countries they already make an agreement (iv) that they 
would distribute this cigarette in their country.

From the example above, the sentence I'm as the first speaker of the Affirmative Team with the motion of "How to ban smoke advertisement on TV" in clause (i) sentence \#1 was used to give initial information by Speaker \#1 of Affirmative Team. Meanwhile, the sentence we know that cigarette is dangerous for our health in clause (ii) sentence \#2, we know that in our country and in some countries they already make an agreement in clause (iii) sentence \#2, and that they would distribute this cigarette in their country in clause (iv) sentence \#2 were used to give factual information to the opposite team. This coincides with Van Dijk's statement (1992) that declaratives provide the information about what beliefs the hearer does not have or accept as yet, and what other general and specific beliefs may be presupposed so as to make such a belief acceptable to the hearer. In other words, declarative is used to make assertion (Gadd, 1999).

Moreover, declaratives are also used to convey certainty; as Halliday points out, a declarative sentence such as 'it is' conveys the highest possible degree of probability, more even than 'it must be' (1994, p. 357). In this case, the speakers wish to appear to be authoritative speakers whose opinions are not to be doubted.

The employment of this declarative could be seen from the following example quoted from Speaker \#1 of Affirmative Team:

Aff. 1:

32. (i) So, at the end, we believe that cigarette advertisement make them any good impact.

14. (iii) they will get easily influenced by this advertisement
22. (ii) and maybe some people never try to smoke

From the examples above, the sentence So, at the end, we believe that cigarette advertisement make them any good impact in clause (i) sentence \#32 was the strongest statement than two others. Meanwhile, the sentence they will get easily influenced by this advertisement in clause (iii) sentence \#14 was medium statement and the sentence and maybe some people never try to smoke in clause (ii) sentence \#22 was the lowest statement.

As seen in Chart 1, Speaker \#2 of Affirmative Team has the highest percentage (22\%) of using declarative in delivering her argument. However, the difference is not significant because the other speakers are around $11-21 \%$. It means that the speakers are not significantly different in using declaratives in their arguments.

In debating, Speaker \#2 of Affirmative Team is responsible for rebutting points made by the Negative, continuing with their arguments, and giving a brief summary of the whole arguments (Sather, 1999, p. 9). In line with this, the speaker mostly uses declaratives to convey their opinions and beliefs through statements in order to convince the audience. Of course, the use of declarative is intended to make assertions (Gadd, 1999): So, we believe that if we put this advertisement on TV, it would make teenagers watch $T V$, they see the adv on $T V$ and they will be curious what are cigarette and many others.In other words that a great majority of declarative mood employed by Speaker \#2 of Affirmative Team shows her assertiveness in delivering her arguments in the debate. 
Declarative Mood Used by the Speakers

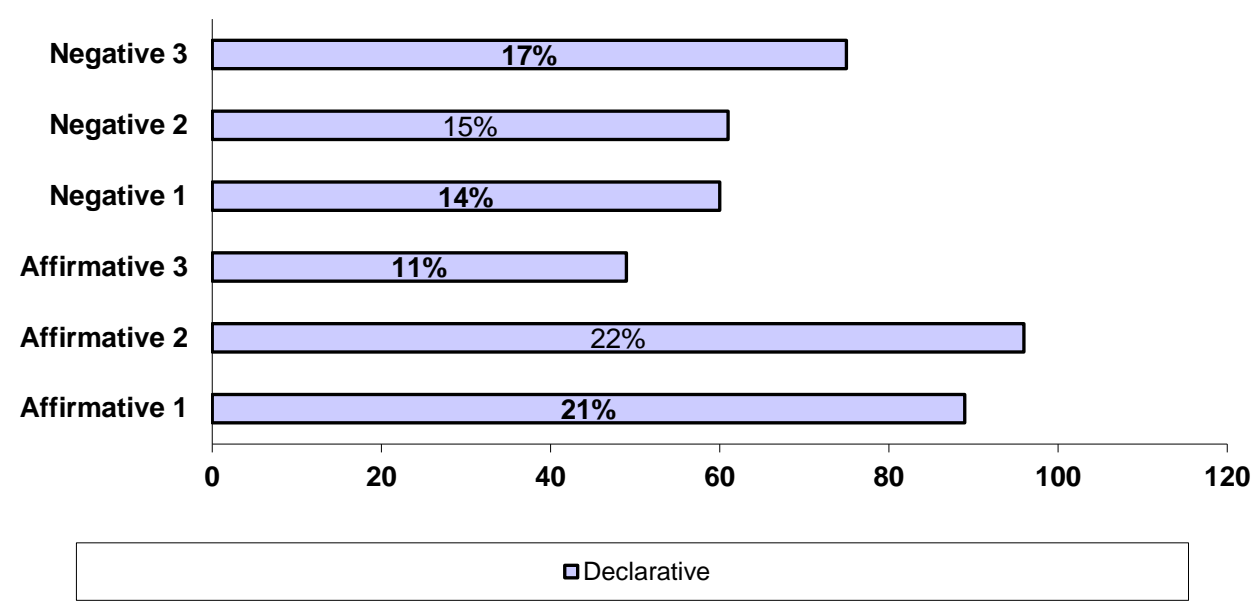

\section{Chart 1:Comparative percentages of declarative mood}

Other than making a direct declarative, the speakers sometimes make it metaphorically. They make question and command in declarative mood, statement and command in interrogative mood, and statement and question in imperative mood. This shows that the incongruent transference in the process of realization of speech functions, such as offer, command, statement and question.One speech function can be realized by various moods, and one mood can realize different speech functions. In interacting with another person, the speaker will inevitably enact one of the speech roles: anything he says will be intended and interpreted as a statement, or a question, or a command or an offer. By acting out a role, he is simultaneously creating a desired role for the other person (even if the other person does not in turn carry out that role): in asking a question, for example, the speaker creates the role of answerer for the other person. However, the speaker may also project a role onto himself or herself or the other person by the way s/he talks about them.

In this debate, commands and questions are mostly realized in declarative mood $(58 \%)$. This indicates that the speakers prefer using declarative mood to metaphorically realize a command instead of the typical use of the imperative mood.Therefore, their speech tone is softened and the social distance between them and the audience is shortened so that they are more likely to get the audience's understanding and support. Also, it is found that debaters sometimes replace declarative mood with imperative mood for the sake of emphasis.

Alternatively, the speakers use statements which are realized in interrogative mood (26\%). It suggests that speakers sometimesplay both of the roles of speaker and audience. They ask a question, and then they answer it themselves. And this makes the debate sound as natural and vivid as if it were a dialogue with the audience. Therefore, the audience is much likely to accept his argument.

In addition to the use of mood metaphor, the speakers also use statements which are realized in imperative mood (16\%). In the debate as Zhixiang (2006) stated,when the speakers want to explain something, they usually use the clause let $m e \ldots$, that is, an imperative tone upon a simple statement. In other words, the 
declarative meaning is metaphorically realized through the imperative structure let me.... This kind of structure serves to make the speaker's presentation sound more authoritative.

As seen on Chart 2, Speaker \#3 of Negative Team has the highest percentage of using mood metaphor (29\%). Meanwhile, the other speakers are around $8-21 \%$. This indicates that in order to convey the messages of the argument, Speaker \#3 of Negative Team prefers using various strategies by using metaphorical forms, to achieve her purpose, such as persuading or evaluating. This is in line with her role in the debate to make summary speech after the floor debate, to review the major issues of the debate, and to leave a lasting impression on the minds of the audience or adjudicators.

Metaphor of Mood Used by the Speakers

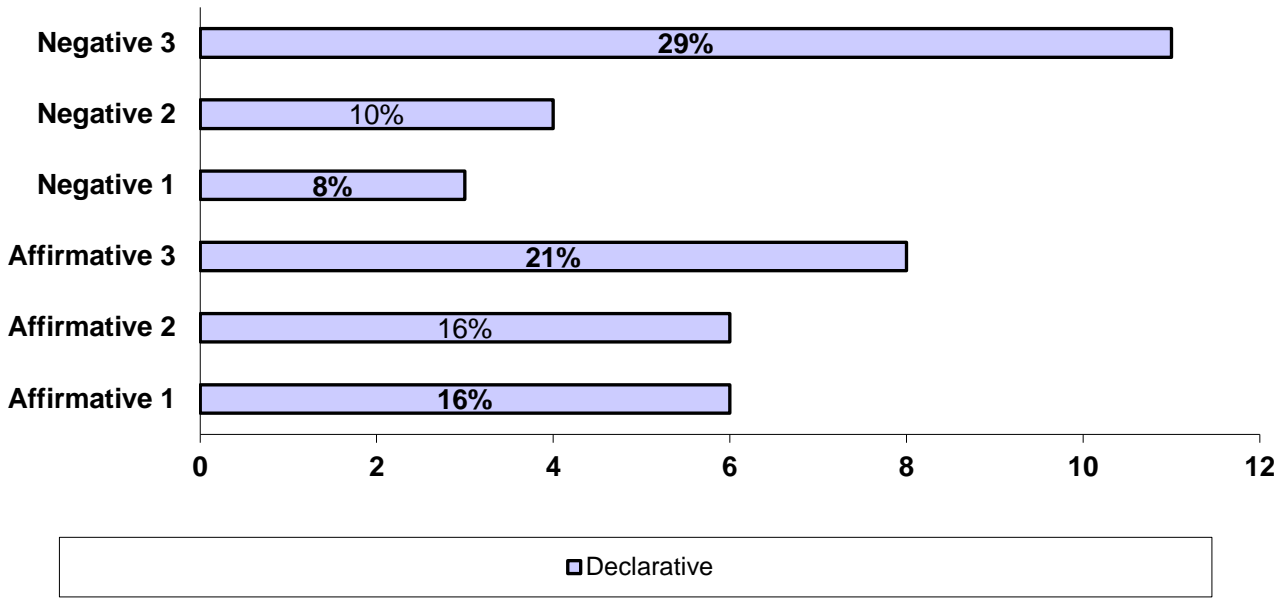

Chart 2: Comparative percentages of mood metaphor

\section{Conjunctive Adjunct}

Conjunctive adjunct links a current clause with prior talk by expressing logical relations of time cause/consequence, condition, addition, contrast, or restatement (Eggins\& Slade, 1997), also, to sequence arguments, or piece of evidence in debating (Martin \&Rose, 2007, p. 138). These play an important role in debating since they make the speakers' arguments sound more assertive.

There are three categories of conjunctive adjunct to be analyzed in this debating data; elaboration, extension, and enhancement.Each type consists of some categories, they are: (i) Elaboration: apposition/appositive and clarifying; (2)
Extension: additive, adversative, and varying; (3) Enhancement; matter, manner, spatio-temporal, and causal-conditional.

Since debating is a formal discussion, the conjunctive adjunct was the most common employed in debating. Textual adjuncts (conjunctive adjuncts) appeared 309 times in all speakers (59\%). This adjunct functions to construct coherence and continuity in debating, with specific adjuncts implying particular logical relations between adjacent clauses (Eggins\& Slade, 1997).Also, to sequence arguments, or piece of evidence in debating(Martin \&Rose, 2007, p. 138). 


\section{Elaboration}

Elaboration in conjunctive relation occurred whereby one sentence is a representation of a previous sentence. In this debating, elaboration was employed 16 times $(5 \%)$ in all speakers except Speaker \#1 of Affirmative Team. This type of conjunction was the least used by the speakers. Here the elaborated element is reinstated in some ways clarified the status of reading for purposes of the text (Halliday\&Matthiessen, 2004, p. 541).

Here in an example of elaboration that was taken from the speaker:

Aff. 2

36. (i) As I say before that (ii) this cigarette corporate has been making a very big advertisement (iii) so that people can get interested in that advertisement.

37.(i) Forexample, the cigarette advertisement usually shows that (ii) the people who do sport like bungee jumping and something else.

For example was used when the Speaker \#2 of Affirmative Team wants to give a clear and straightforward explanation of the previous sentence by giving an example.

\section{Extension}

This conjunctive relation is a relationship of addition, adversity, or variation. Extension was one of the most commonly employed by all speakers in debating. It appeared 166 times (54\%). The following sentence was taken from a speaker in debating:

Neg. 1

5. (i) But let's see that the adv on TV are begun at 9 o'clock in the night.

6. i) And I'll explain further more about the main case.

In the example above which was taken from Speaker \#1 of Negative Team, the conjunction and joined ideas of both sentences that are related with each other. Therefore, and is an additive conjunction that extends the element by positive addition (Halliday and Matthiessen, 2004, p. 543).

\section{Enhancement}

Enhancement in conjunctive relation occurred to ways whereby one sentence can extend on the meanings of another, in terms of dimensions such as time, comparison, etc. (Halliday\&Matthiessen, 2004, p. 545). In this debating, enhancement was employed 127 times $(41 \%)$. Here is an example of this type:

Aff. 2

42. (i) It's a very unique (ii) and it's like fun, (iii) so that there is a big possibility (iv) that they will try this,(v) they will try (vi) what the people do in this advertisement.

So that was used to say that after noticing the previous clauses, there is a big possibility is a truly important thing to be highlighted. Therefore, so that is a positive matter of enhancing terms. This sentence was taken from Speaker \#2 of Affirmative Team.

As seen on Chart 3, Speaker \#2 of Affirmative Team has the highest percentage of using conjunction (25\%). Meanwhile, the other speakers are around $11-20 \%$. This indicates that Speaker \#2 of Affirmative Team is extremely well to create cohesion in her arguments since conjunctive adjunct acts to connect messages in the discourse (Martin \& Rose, 2007, p. 143). This fact further says that a great majority of conjunction employed by Speaker \#2 of Affirmative Team shows her assertiveness and critical thinking through cohesive arguments in debating.

The analysis of conjunctive adjunct tells the structure of logical relation. This inferres that all speakers convey their 
arguments through elaboration, extension, and enhancement. In this debate, the argument is largely hold together by extending relations, which is $54 \%$ of the debate; they are addition (123 items), adversative relation (24 items), and variation (19 items). It means that the speakers' concern is to tell audience the supplementary information in order to improve it or make it complete, as well as the link among sentences, or the variation of meaning of the motion.

On the other hand, spatio-temporal and causal-condition were the most common employed of enhancement in this debate as well; both of them are causation and consequence where the speakers' concern is to tell their audience both why things happened and what would be the result of them. For example, thus, so are used to signal that a conclusion is construed as the expected outcome of the argument that has been presented. First, second, next, then are used to sequence arguments, or piece of evidence in the debate (Martin and Rose, 2007, p. 138).

\section{Conjunction Used by the Speakers}

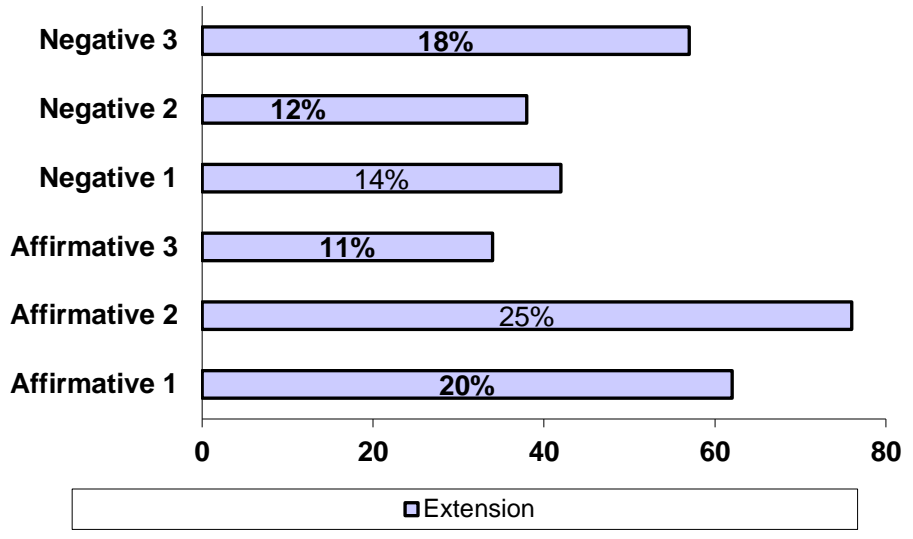

\section{Chart 3: Comparative percentages of conjunction}

Moreover, elaboration is rarely used in delivering arguments. It suggests that the speakers rarely use exemplifying and giving exploratory when they deliver their arguments. Whereas, giving examples and explanations are crucial in a debate.

\section{High value of modality}

As a part of modality system, modality value refers to the extent to which a speaker commits him/herself to the validity of what $\mathrm{s} / \mathrm{he}$ is saying or it is the "value attached to the modal judgment": high, median or low (Halliday, 1994, pp. 354-367).
High value of modality was employed in all speakers with 45 occurrences (28\%) which consisted of $25 \%$ of high probability and $3 \%$ of high obligation. There was no employment of high usuality and high inclination in debating. The employment of this type of modality value could be seen in the examples below. The following example was quoted from Speaker \#3 of Affirmative Team:

Aff.3

15. (i) We won't let the society to smoke(ii) because webelieve that smoking is dangerous (iii) because there is a lot of dangerous ingredients in the cigarette 
such as ...., nicotine (iv) that can damage the people's health.

The speaker employed believe as the cognitive verbs in mental clauses that show high probability. It is metaphorical realization. For consideration, there was no employment of modal operators or mood adjuncts which were used to show high probability.

The next example was taken from Speaker \#1 of Affirmative Team:

Aff. 1

17. (i) We the government team, as the government implicitly force Cigarette Company.

Force, in the sentence above, is a causative verb that was used to show a high obligation (Halliday\&Matthiessen, 2004, p. 513). According to Halliday\&Matthiessen, causative verb force has the same meaning with must, which shows a high obligation. In addition to the expression of high obligation, the nominalization obligation was used by the speaker. While, modal operator have to was used by Speaker \#3 of Negative Team to express a high obligation in sentence \#47 (Gerot\&Wignell, $1994, \quad$ p. 26; Halliday\&Matthiessen, 2004, p. 624).

'Probability' is dominantly used by the speakers in delivering their arguments. The use of probability by the speakers indicates that most speakers in the debate convey their opinion with median certainty since epistemic interpretations have to do with knowledge and understanding regarding the level of certainty of a proposition's truth (Griffiths, 2006, p.111). In the debate, as seen in Chart 4, Speaker \#1 of Affirmative Team, who has the highest percentage of using median probability (34\%), use modal operator (will, would) and mental verb (think) to show their median level of certainty. Meanwhile, the other speakers are around $8-18 \%$.

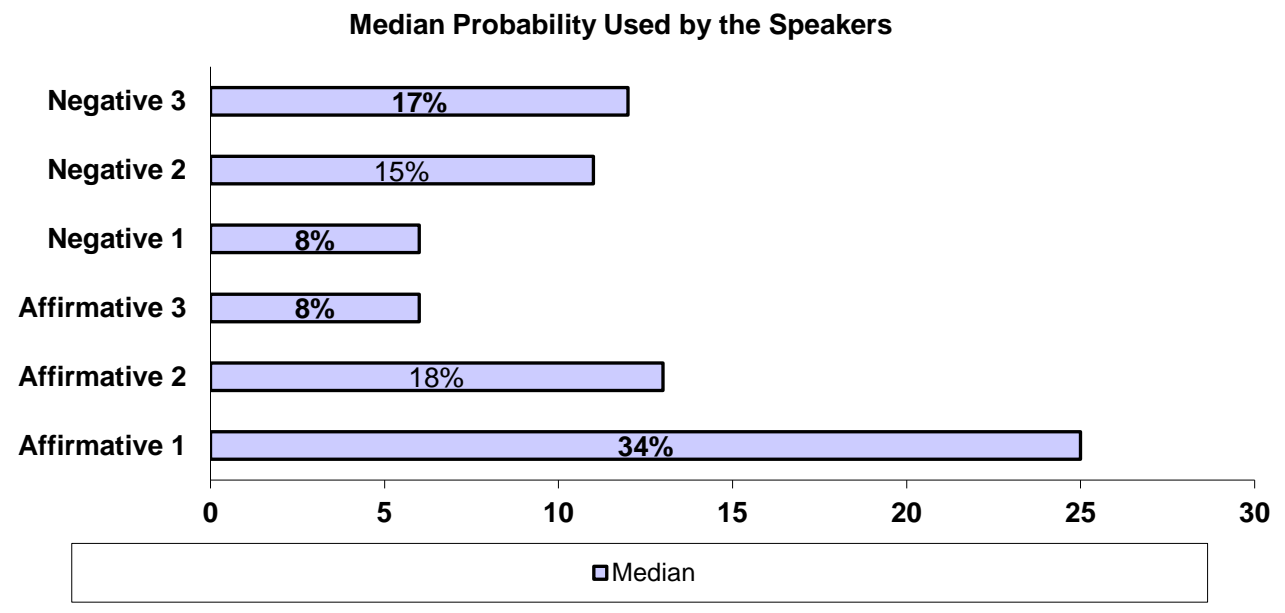

\section{Chart 4: Comparative percentages of median probability}

Moreover, the speakers use high probability $(25 \%)$ to deliver their arguments since they must convince audience concerning their opinion. In line with Martin, et al. (1997, p. 70), by using mental verbs (know, believe, realize, see) the speakers have high level of certainty to what they understand. In other words, they confidently deliver their knowledge and understanding through high probability. As the rest, low probability is expressed through mood 
adjunct (maybe) to show the speakers' low level of certainty.

\section{Explicit subjective modality}

There are four types of Orientation and Manifestation of Modality that occured in debating; they are implicitly subjective, implicitly objective, explicitly subjective, and explicitly objective.

The speakers express explicit subjective modality through mental verbs such as know, believe, realize, see, think and causative verb 'force' (=must). Meanwhile, implicit objective modality is expressed through mood adjunct (maybe, usually) and predicator (is/are to, are supposed to). Also, implicit subjective modality is shown through finite modals (would, will, can, should, have to) and explicit objective modality is expressed through nominalization (it's obligation, it's possibility).
As previously mentioned, the dominant orientation and manifestation of modality is explicit subjective modality. This indicates that the debaters try to give the prominence to their point of view and to highlight the firmness of their attitude or belief so as to win the audience's support and understanding (Zhixiang, 2006). By using mental verbs (know, believe, think, realize, see, feel, want, tell, say, try), the debaters explicitly construct themselves as the source of theassessment, and to some extent, place their authority to assess at risk (Martin, 1995, p. 23). In line with this, Halliday and Matthiessen (2004, p. 624) state that explicitly subjective modality is the most effective way to give prominence to the speaker's own point of view since modality represents the speaker's angle; either on the validity of the assertion or on the rights and the proposal.

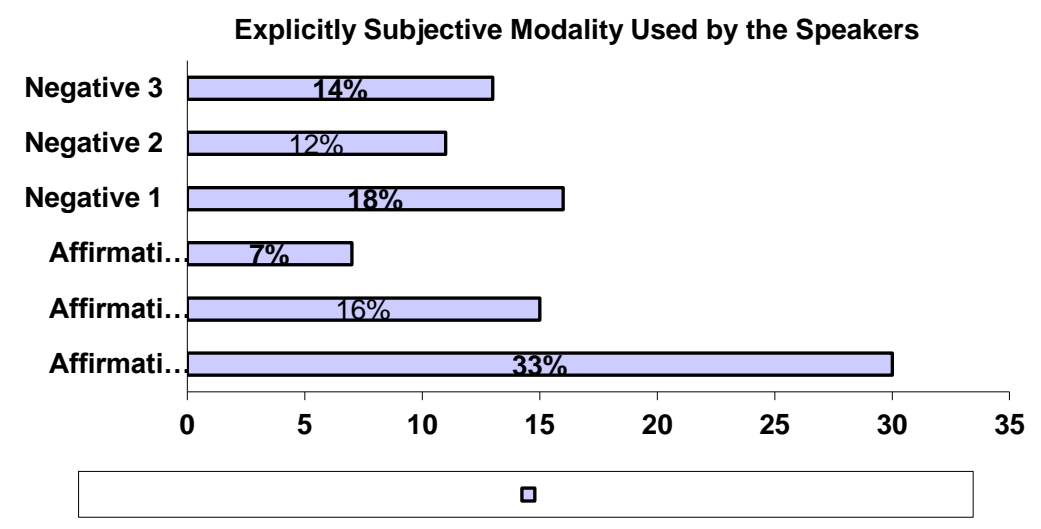

\section{Chart 5: Comparative percentages of explicitly subjective modality}

Clearly shown in Chart 5 , as the most dominant participant that uses explicit subjective modality, Speaker \#1 of Affirmative Team shows her assertiveness prominently through some mental verbs (we know that..., we believe that..., we realize that...). Especially, Speaker \#1 of Affirmative Team is a starter of the debate who defines the motion, describes exactly what the basis for debate will be, explains any ambiguous words, sets any limits to the debate, interprets the motion as a whole, and states exactly what contention is going to be tried and proved.

\section{Explicit subjective modality metaphor}

As regards with the modality metaphor, the explicitly subjective and explicitly objective forms of modality are all strictly speaking metaphorical, since all of them represent the 
modality as being the substantive proposition.

Explicitly subjective form of modalityis shown through clauses which based on the semantic relationship of projection. In this type, the speaker's opinion regarding the probability that his observation is valid is coded not as a modal element within the clause, which would be its congruent realization, but as a separate, projecting clause in a hypotactic clause complex. For example, to the congruent form it probably is so corresponds with the metaphorical variant $I$ think it is so, with $I$ think as the primary or 'alpha' clause (Halliday, 2000, p. 354). The reason for regarding this as a metaphorical variant is that the proposition is not, in fact, I think; the proposition is it is so.

In the debate, debaters sometimes would like to emphasize the subjectivity of their points of view so as to make one's statement more assertive; and the most effective way of doing that is to dress it up as if it was this that constituted the assertion ('explicit' Ithink)(Halliday, 2000, p. 362). The subjective nature of the assessment is reinforced by the modality in a separate clause.

Alternatively, explicitly objective form of modalityis represented through nominalization, such as: possibility, probability, likelihood, certainty, unusualness, regularity, typicality, intention, desire, determination, need, obligation, regulation, compulsion and so on. By means of these nominalizations, modality is construed as an unquestionable fact i.e. modality is expressed explicitly with objectivity.

In line with this, Halliday and Matthiessen(2004, p. 362) points out that one of the most effective ways of creating objectivity is through the use of explicitly objective form of modality. By using it, the speaker can make his or her point of view appear to be a quality of the event itself because this objectification is clearer in cases where the modality is expressed in a separate clause, namely in explicitly objective form.

\section{Level Assertiveness of Debaters}

There are five elements that would be considered in meazuring the level of the assertiveness among the six speakers, they are the total of declarative mood, conjunctive adjunct, high value of modality, explicit subjective modality metaphor, and explicit subjective modality.

The result of the analysis above is presented in Table 1 regarding the mood and modality analysis which is considered as assertiveness indicators in the six speakers, and will be compared among them based on the level of its assertiveness.

As seen on Table 1, Speaker \#1 of Affirmative Team has the greatest number of total high value of modality among other speakers, which are 19 items. She also employed the greatest number of total explicitly subjective of modality metaphor and total explicit subjective of modality among other speakers, which are 21 items and 30 items, respectively. She also employed high number of declarative mood with 89 items and total of conjunctive adjunct with 62 items.

Speaker \#1 of Negative Team employed 60 declarative moods, 42 conjunctive adjuncts, 16 explicitly subjective of modality, 5 high value of modality, and 4 explicit subjective of modality metaphor.

Speaker \#2 of Affirmative Team employed the greatest number of total declarative mood among other speakers, which are 96 declaratives. Meanwhile, the other speakers are around 49-89 items. Speaker \#2 of Affirmative Team also employed the greatest number of total conjunctive adjunct among other speakers, 
which are 76 conjunction, while the others are around 34-62 items. She has medium number of total high value of modality with only 11 items, explicitly subjective of modality metaphor with 9 items, and explicit subjective of modality with 15 items.

Table 1: Number of assertiveness indicators of the speakers

\begin{tabular}{|l|c|c|c|c|c|c|c|}
\hline & $\begin{array}{l}\text { Aff. } \\
\mathbf{1}\end{array}$ & $\begin{array}{l}\text { Neg. } \\
\mathbf{1}\end{array}$ & $\begin{array}{l}\text { Aff. } \\
\mathbf{2}\end{array}$ & $\begin{array}{l}\text { Neg. } \\
\mathbf{2}\end{array}$ & $\begin{array}{l}\text { Aff. } \\
\mathbf{3}\end{array}$ & $\begin{array}{l}\text { Neg. } \\
\mathbf{3}\end{array}$ & Total \\
\hline 1. Total of declarative mood & 89 & 60 & $\mathbf{9 6}$ & 61 & 49 & 75 & 430 \\
\hline 2. Total of conjunctive adjunct & 62 & 42 & $\mathbf{7 6}$ & 38 & 34 & 57 & 309 \\
\hline 3. Total of high value of modality & $\mathbf{1 9}$ & 5 & 11 & 4 & 2 & 4 & 45 \\
\hline $\begin{array}{l}\text { 4. Total of explicitly subjective of } \\
\text { modality metaphor }\end{array}$ & $\mathbf{2 1}$ & 4 & 9 & 8 & 4 & 8 & 54 \\
\hline 5. Total of explicit subjective modality & $\mathbf{3 0}$ & 16 & 15 & 11 & 7 & 13 & 92 \\
\hline Total & $\mathbf{2 2 1}$ & $\mathbf{1 2 7}$ & $\mathbf{2 0 7}$ & $\mathbf{1 2 2}$ & $\mathbf{9 6}$ & $\mathbf{1 5 7}$ & $\mathbf{9 3 0}$ \\
\hline
\end{tabular}

Meanwhile, Speaker \#2 of Negative Team employed 61 declarative moods, 38 conjunctive adjuncts, 11 explicit subjective of modality, 8 explicitly subjective of modality metaphor, and 4 high value of modality.

Speaker \#3 of Affirmative Team employed 49 declarative moods, 34 conjunctive adjuncts, 7 explicit subjective of modality, 4 explicitly subjective of modality metaphor, and 2 high value of modality.

As the last speaker, Speaker \#3 of Negative Team employed high number of declarative moods with 75 items, followed by 57 conjunctive adjuncts, 13 explicit subjective of modality, 8 explicitly

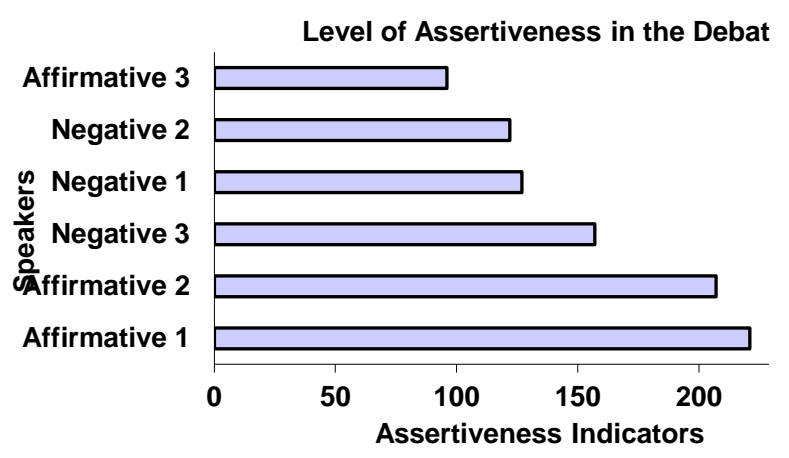

Chart 6: Level of assertiveness subjective of modality metaphor, and 4 high value of modality.

Overall, as seen in Chart 6, Speaker \#1 of Affirmative Team employed the greatest number of mood and modality devices which were used to measure assertiveness that is 221 items, while the others are around 96207. This indicates that Speaker \#1 of Affirmative Team is the most assertive speaker in delivering her arguments in the debate. The second place is Speaker \#2 of Affirmative Team with 207 items, followed by Speaker \#3 of Negative Team with 157 items, Speaker \#1 of Negative Team with 127 items, Speaker \#2 of Negative Team with 122 items, and the last is Speaker \#3 of Affirmative Team with 96 items. 


\section{CONCLUSION}

Based on the main findings above, this study concludes that all the analyzed arguments used by the debaters are assertive since argumentativeness can be understood as a subset of assertiveness; all argument is assertive, but not all assertiveness involves argument (e.g., a request) (Rancer, 1998). However, there is a difference in the level of assertiveness depending on how the debaters deliver their arguments. Therefore, a variety of ways is needed by the debaters to make their argument sounds more assertive.

Mood and modality analysis has shown what principles exist that creates semantic links in the arguments between sentence and clause. This analysis is helpful to understand the interpersonal meaning of the debate from a new perspective, which elaborates the subtleties of language use in this kind of genre and helps us have a better understanding of it. This analysis demonstrates that Systemic Functional Grammar, characterized by its multi-level and multi-function, could provide us with a theoretical framework for genre analysis. Moreover, through the functional analysis, we find that language form is consistent with its function. Therefore, such a study suggests that similar analysis could also benefit English learners in their improvement of their English listening, speaking and writing so that they can develop their communicative competence more effectively.

This study has examined the level of assertiveness of the debaters. There are some important things that need further consideration for future research. This study is limited in terms of reference materials and time limitation, it is difficult for the investigation to be comprehensive and exhaustive and many aspects of the functional grammar and pragmatics in Senior High School's debate remain untouched. Since senior high school's debate is only a small part of public debates, it may not be typical enough to represent the public debate genre. Finally, the data comes from the author's own calculation, which may involves some margin of errors.

\section{REFERENCES}

Braga, D \&Marques, M. A. (2004).The pragmatics of prosodic features in the political debate. Portugal: University of Minho.

Derewianka, B. (1990).Exploring how texts work, Sydney: PETA.

Eggins, S\&Slade, D. (1997). Analysing casual conversation. London: Cassell.Edinburgh: Edinburgh University Press.

Emilia, E. (2009). Argumentative writing. Bandung: Indonesia University of Education.

Feez, S., \& Joyce, H. (1998). Writing skills. narrative and nonfiction text types. Melbourne: Phoenix Education Pty. Ltd.

Gadd, N. (1999). A systemic functional analysis of a televised political debate before the 1996 Australian federal election. Melbourne: University of Melbourne.

Gerot, L \& Wignell, P. (1994). Making sense of functional grammar. An introductory workbook. Sydney: Antipodean Educational Enterprises.

Griffiths, P. (2006). An introduction to English semantics and pragmatics.

Halliday, M. A. K.(1994). An introduction to functional grammar. New York: Edward Arnold.

Halliday, M.A.K. \& Matthiessen, C. (2004). An Introduction to functional grammar.Third Edition. London: Arnorld.

Marshall, et al. (2008). Using a headmounted video camera to understand social worlds and experiences. 
Sociological Research Online, 13(6). Retrieved fromhttp://www.socresonline.org.uk/13/ 6/1.html

Martin, J.R. (1995). Interpersonal meaning, persuasion, and public discourse: Packing semiotic punch. Australian Journal of Linguistics 15, pp. 33-67.

Martin, J.R, \& Rose, D. (2007). Working with discourse. London: Continuum.

McGregor, R. (2001). Analysing and writing arguments 1. Exploring and using the language of arguments. Melbourne: English Club.

Rancer, A. S., (1998). Argumentativeness. In J.C. McCroskey, J.A Daly, M.M. Martin, \& M.J. Beatty (Eds.), Communication and personality: trait perspective (pp. 149-170). Cresskill, NJ: Hampton Press, Inc.

Riddle, D. I. (2008). Assertiveness principles. Canada: Service-Growth
Consultants Inc.Available on http://www.servicegrowth.net/document s/Assertiveness\%20Principles.net.pdf. [January 19, 2010]

Sather, T. (1999). PROS and CONS: A debater's handbook.Oxon: Routledge.

Shulman, M. (2004). Thinking critically: world issues for reading, writing and research. Ann Arbor: The Univerisity of Michigan Press.

Travers, M. (2001). Qualitative research through case studies. London: SAGE Publication Ltd.

Van Dijk, T. A.(1992). Racism and Argumentation: "Race Riot" Rhetoric in Tabloid Editorials. In: F. H. van Eemeren, et al. (Eds.), Argumentation illuminated. (pp. 242-259).Dordrecht: Foros.

Zhixiang, Z.(2006). A functional analysis of interpersonal GM in political debates.Unpublished Thesis. 